\title{
Conservative-Progressive Power Games, Mutual Jostling in Africa and Resilience of Sino-African Relations under COVID-19 Wind
}

\author{
Benjamin Mwadi Makengo \\ School of Politics and International Studies, Central China Normal University, Wuhan, China \\ Email: benjaminmwadi@yahoo.com
}

How to cite this paper: Makengo, B. M. (2021). Conservative-Progressive Power Games, Mutual Jostling in Africa and Resilience of Sino-African Relations under COVID-19 Wind. Open Journal of Political Science, 11, 439-460.

https://doi.org/10.4236/ojps.2021.113030

Received: April 26, 2021

Accepted: July 9, 2021

Published: July 12, 2021

Copyright $\odot 2021$ by author(s) and Scientific Research Publishing Inc. This work is licensed under the Creative Commons Attribution International License (CC BY 4.0).

http://creativecommons.org/licenses/by/4.0/

\begin{abstract}
By taking the subprime crisis as its historical fact of analysis and game theory as its theoretical explanatory basis, this paper aims to explain and demonstrate why Sino-African relations may well withstand in the ongoing "conservative-progressive power games" in Africa under COVID-19 wind, even though they are being further jostled by the "conservative's offensive". To support my central point, I start from the assumption that, as was just the case with the subprime crisis, the socioeconomic and financial dimension will once again become a compass [but also a barometer] in the decisions and actions of all the states at stake-the "conservatives", the "progressives", as well as the different African countries. Thus, the improvement of the socioeconomic and financial situation on its own territory will become the major challenge of almost all these states at stake. And China, which is less affected by the socioeconomic and financial crisis caused by COVID-19 than the "conservatives", will be well able to bear the costs of its increasing engagement on the African continent. Although a relative decline or quasi-stagnation of its engagement on the continent can be noted-but rather less than in the case of the "conservatives", due of course to the comparative shocks of this crisis caused by COVID-19 on their economic activities. In this same logic, another explanatory point is that, if Sino-African relations fall, a big hole will be left in African economies-because of China's pronounced economic integration in Africa. A hole that the "conservatives"-hit hard by this crisis due to COVID-19, will not be able to fill during this critical moment, in the sense of satisfying the demands of Africa-which is also hit hard by the same crisis. Finally, the game theory as an explanatory theoretical basis, via the five (5) points game, imagined in terms of gain on the African continent, according to the costs of "conservative-progressive engagements"-which are conditioned here by the socioeconomic and financial crisis due to COVID-19,
\end{abstract}


demonstrates as well this affirmation of the resistance of Sino-African relations. In this game, following the assumptions put forward, the most possible scenario is the one that affirms that: Sino-African relations and "conservatives" both withstand. Because, China, less affected by the socioeconomic and financial crisis due to COVID-19, will still be able to bear the costs of its engagement on the African continent. But also, in the case of the fall of the "conservatives", China alone will not be able to fully cover the gap left by them due to the crisis caused by COVID-19, which also negatively impacted its economy and finances. And the point remains to think about the postCOVID-19 scenario of these "conservative-progressive power games" on the African continent.

\section{Keywords}

Conservative-Progressive Competition, Mutual Jostling in Africa, Power

Games in Africa, Sino-African Relations' Resilience under COVID-19 Wind

\section{Introduction}

A health miracle has happened in Africa. With the coronavirus disease pandemic of 2019 (COVID-19), beyond all unfortunate understandings, Africa is doing rather better than the most advanced continents in terms of health ${ }^{1}$. The various projections made according to states' capacity to cope with COVID-19 [according to the required health standards] are rather beaten in breach by another reality of the facts on the ground than the one expected ${ }^{2}$. The worst has not happened in Africa. Who exactly can explain this? Is the African climate, the repetitive use of anti-malarial drugs, African foodstuffs, the low level of African integration into global flows, or the rapid awareness and reaction [in the case of confinement for example] of Africans to the danger posed by COVID-19 to the continent, the reasons for this? Are there others? Who knows? Whatever the health miracle happened, Africa should learn and understand the various lessons that COVID-19 has come to give it. The miracle does not happen every time, it is high time for Africa to wake up from its deep sleep, otherwise disaster is coming. On the other hand, the worst that is looming in Africa is rather socioeconomic-financial [except for the health sector due directly to COVID-19 covered by the miracle]. And on the other hand, it is the observation concerning the international politics' dimension on the continent. These are the power games

${ }^{1}$ According to the European Centre for Disease Prevention and Control, the overall number of cases of contamination due to COVID-19 reached 1,168,735 in Africa, 6,071,338 in Asia, 12,326,095 in the Americas, 3,383,338 in Europe and 27,197 in Oceania on August 22, 2020. The number of deaths reached 27,320 in Africa, 126,791 in Asia, 439,405 in the Americas, 206,290 in Europe and 508 in Oceania on the same date.

${ }^{2}$ Some people saw the worst in the African continent compared to what was happening in China, Europe and the United States. Similarly, the WHO also thought the same, through the statement of March 18, 2020 of its Director General Tedros Adhanom Ghebreyesus, during a virtual press conference in Geneva, I quote: "The best advice to give to Africa is to prepare for the worst and to prepare today". 
that are increasingly being drawn, redrawn, raised and reemerged on the African continent during this macabre period of sad memory of the COVID-19 pandemic.

Because it is quite clear that, beyond the health dimension, the COVID-19 pandemic has indeed moved world politics. In the four corners of the globe, different events are constantly coming up and going up. Events should happen over time. But alas, COVID-19 has just come to accelerate them. And the most important of these events in the international arena is the rise of US-China competition, better the "conservative-progressive competition". Competition between those who want to maintain their dominance, power and influence around the world, in such in a region, activity or field-the "conservatives", and those who push for change-the "progressives" - competition of older against newer influences (Makengo, 2020c: pp. 188-203; Makengo, 2020d: pp. 113-129). Of course, United States and China are the leaders of these two blocs- "conservative" and "progressive", respectively. A competition that existed long before COVID-19, it has just risen to a higher level than before COVID-19, and it is evident in different world's corners and in different fields-in the form of power games. These are taking shape and are still taking shape most clearly in the various fields or areas that are considered strategic by all sides ${ }^{3}$. And the African continent is no exception. But why is that? The question here is to ask: is Africa or can it still be considered as a [strategic] power games playground? And why? Or just, at this beginning of the twenty-first century, does Africa still matter for it to be considered as a power games playground?

However, many scholars often wrongly omit Africa from the great debates of the power games in the international arena, while others just relegate it to the back burner. They support the idea that: Africa matters less in power games compared to other different world's corners. Because the "black gold", the oil to be controlled at all costs would be elsewhere and not on the African continent. The approximately $12 \%$ of Africa's "black gold" reserve is of little importance. As Frédéric Encel (2011: pp. 281-292) also thinks, the "black gold" has a value of choice that one does not cease to grant to it since the twentieth century in the international arena, especially because of the increasing military and civil necessities of the industrialized countries in it. Thus, as Philippe Tristani (2010: pp. 81-107) also notes, following the world essence and the interregional balance that the "black gold" requires, the oil economy commands a particular geopolitics. And it is the Middle East which is more targeted-with about $60 \%$ of its world reserves of "black gold" (Encel, 2011). This makes its oil for some scholars, not only as one of the keys of the contemporary world, but also, as one of the main engines of the wars and struggles that frequently affect it-a provider of tension and instability (Encel, 2011; Chatelus, 1974: pp. 1-303). In the same way also, as Philippe Tristani (2010) still points out, the control of the "black gold" of the Middle East does not cease being in the heart of great powers' con${ }^{3}$ I'm thinking here of the South China Sea, the island of Taiwan, the Middle East, the advanced technology... 
flicts. In his book: The international politics of the Middle East, Raymond Hinnebusch (2003: p. 1) also underlines that, the Middle East is well the place center of the world geopolitics, the place of the chronic and of longer wars and conflicts of the world, the region where the anarchy and the security, that the school of the political realism advocates, is observed in the most relevant way. And also, those scholars who put Africa aside, moreover, support this exclusion according to the idea that, there would be no great power in Africa or even a rising power that can threat the security and survival of the existing powers (Mearsheimer, 2001: pp. 1-555; Mearsheimer, 2018: pp. 1-319). Rather, this paper proposes to demonstrate the contrary, by highlighting the geopolitical dimension, following the approach of strategic analysis. If the stakes of "black gold" would be outside the African continent, but rather the stakes of "gray or blue gold", of cobalt are indeed on the African continent... The new global stakes of the energy transition and digital may well demonstrate it (Makengo, 2020b: pp. 51-75). And although, until further notice, Africa does not yet register a great power on its continent, but rather it ostensibly attracts the different great powers in its different corners. The colonial era, as well as the neo-colonial era, of the "US-ex-Union of Soviet Socialist Republics (USSR)" and "Anglo-Saxon-Francophone competitions"driven by France and US, which occurred on the continent, can better demonstrate it (Chari, 2010: pp. 1-253; Lightbody, 1999: pp. 1-141; Levinger, 2016: pp. 1-58; Magnarella, 2005: pp. 801-822; Reyntjens, 2009: pp. 1-339). At the beginning of the twenty-first century, with China's increasing engagement on the continent, it is the "conservative-progressive competition", as already pinned above, that best demonstrates it. And COVID-19 has just come to unmask this observation, to shed light on the near-blackness of the geopolitical rivalries that were well hidden, and to unveil the merciless power games on the African continent that had been well veiled.

And in these games, each actor and block tries to pull the sheet to it side. Winning the heart of the African continent by all means-in order to better ensure its interests-is indeed what is at stake. Africa, once in the bosom of the Western world-the "conservatives", is no longer the case today. Since the beginning of the twenty-first century, China's increasing engagement-the "progressives"4-on the continent has changed the situation (Makengo, 2020a: pp. 191-216). The growing Chinese presence in Africa continues to push the declination of "Western-African relations". And the West-["conservative"]-seeks at all costs to maintain its influence, domination and interest on the continent. For its part, China-["progressive"] -also continues to push in the opposite direction [i.e. for change]. But under COVID-19 wind, "soft power" is coming to the forefront of "hard power" in these games, attracting the African continent in its favor in a "soft engagement" at the expense of the other. The hard power plays just indirectly in terms of the threatened and influences African decisions and actions in these games (Nye, 1991: pp. 1-306; Nye, 2004: pp. 1-191; Nye, 2008: pp. 1-226; Nye, 2011: pp. 1-298). By ricochet, communication in the broad ${ }^{4} \mathrm{I}$ am also thinking of the resurrection of Russia's engagement on the continent. 
sense-including the dimension of public diplomacy, donations, aid, solidarity initiatives, diplomatic contacts and visits are in the foreground (Makengo, 2020c: p. 191). Here, the observation made during this pandemic in these power games in Africa is that the sum of "conservatives' soft power" seems to be the most powerful compared to that of the "progressives"-China. Of course it does, ostensibly for historical reasons-colonial ties and legacies-sharing a number of "values", beliefs and other cultural bases-language for example, and communicational integration-the communication system of the "conservatives"-[their public diplomacy]-is more integrated in Africa than that of the "progressives". As a result, Sino-African relations are increasingly [or more] being shaken up in these power games on the African continent during this period of the COVID-19 pandemic. Trends before and at the onset of the COVID-19 pandemic are increasingly changing on the continent. The "conservatives" are now going on the offensive. The "progressives"-China, are increasingly retreating to the defensive. Two blocs are jostled each other mercilessly on the continent. And in this jostling, with the weaknesses of "Chinese's soft power" against the strengths of the "conservatives' soft power" on the continent, the question here is: can Sino-African relations withstand? Will these relations withstand to the "conservatives' fierce offensive" on the African continent in this COVID-19 era?

Thus, in order to provide clear explanatory answers to the questions raised above, this paper proposes first of all not only to make a diachronic configuration of the power games in Africa before COVID-19 (ii), through the colonial era to this twenty-first century, in order to arrive at a synchronic brushing of these games, also to explain the reason for these power games on the African continent, by trying to say if Africa is [still] matter for it to be a field of these games. But also to demonstrate the extent to which COVID-19 came to play the events' accelerator role through the rise in level of "conservative-progressive power games" in Africa (iii), focusing on the "conservative offensive" and the "progressive defensive"-of China, on the continent during this COVID-19 period, to expose the factual record of the further jostling of Sino-African relations during this COVID-19 era. And then, to answer the question: can Sino-African relations withstand? (iv), taking the economic-financial crisis of 2008 as a historical fact of analysis, in order to understand the actors' behaviors and rationalities in power games in Africa during this period of the wind of the socio-economic-financial crisis due to COVID-19. And game theory as an explanatory theoretical basis of analysis to better understand the imposing rational logic in these power games in Africa during this period of the socio-economic-financial crisis' wind due to COVID-19. This in order to be able to identify the scenario as much as possible, which can say about the resistance or not of the Sino-African relations in these power games in Africa under this COVID19 era.

${ }_{5}^{5}$ Just to illustrate: the media have more inks on the African continent than the Chinese media. France 24, TV5, BBC, RFI, CNN... are better followed in Africa than CGTN, CCTV... 


\section{Power Games in Africa before COVID-19}

When talking about power games, this paper alludes to the competitions of the great powers in a given space, looking for the same thing, the same title and/or position, thus expressing the idea of a rivalry between them. Over here, it is imperative to situate oneself in time. Because the era before COVID-19 covers a long and rich historical span of time on the African continent. But just by referring to the colonial era, the power games on the African continent can be well traced. From the fifteenth century to the end of the Second World War, covers the era of "colonial power games" in Africa. The colonial powers of that time succeeded in dividing Africa into borders according to their will and interests (Grenouill, 2004: pp. 1-247; Oliver \& Atmore, 2005: pp. 1-405). Gaining more colonies and strategic corners than the others was indeed the major stake of these "colonial games". From the end of the Second World War, the decolonization movements gained momentum, it is the era of independence of African countries. The colonial powers after the Second World War, notably France, England and Portugal, no longer knew how to control their colonial empires. Another configuration should then be created. Hit hard by the costs of the war on the one hand, the rise of decolonization movements, and the push of the United States and the USSR in favor of these movements on the other hand, the colonial powers finally conceded (Brocheux, 2012: pp. 1-280; Makengo, 2021: pp. 212-233). Thus, the colonial empires were let go, but not totally. This is the beginning of the birth of the "neo-colonial power games" in Africa. Gaining more allies, relatives, zones of influence and territories to control than others is what is at stake in these games. First, these "neo-colonial power games" in Africa were dominated by East-West, "Capitalist-Communist competition" during the famous US-USSR Cold War. Then, just after the fall of the Berlin Wall in 1989 and the break-up of the USSR with fifteen (15) states in 1991 (Lightbody, 1999), these games should only change face. The USSR is no longer included in the competition, but rather yesterday's allies are now opening up another face of these games. I am thinking here of the "Anglo-Saxon-Francophone competition", dominated respectively by the United States and France during the last ten years of the end of the twentieth century, more particularly in the African Great Lakes region. Just the reading and rereading of the 1994 Rwandan genocide's problematic, can say more about it" (Levinger, 2016; Magnarella, 2005; Reyntjens, 2009).

\subsection{And How About in the Twenty-First Century?}

Just at the beginning of the twenty-first century, another face of these power games on the African continent was constantly emerging. Indeed, it is, in fact, mainly due to the rise of China. Since the organization of the first Forum on China-Africa Cooperation (FOCAC) in 2000, China's engagement on the African continent has taken another direction, that of an upward trend (Makengo, 2020a). A growing Chinese presence has been noted over the last twenty years 
on the African continent. On the other hand, there has been a considerable decline in the presence of Western powers on the continent over the last twenty years. China's increasing engagement in Africa is implicitly causing the decline of the Western powers' involvement on the continent. Just the evolution of African trade data with the rest of the world can better demonstrate this. Around the year 2000, Sub-Saharan Africa's exports and imports to China accounted respectively for about 2 percent and 3 percent of the global total, rising to about 14 percent and 16 percent, respectively, by 2019, of total Sub-Saharan Africa's and the rest of the world's total trade. The graphs below, which show a comparative evolution of Sub-Saharan Africa's exports and imports to China, Russia and the various Western powers, are a better illustration of this (see Figure 1, Figure 2).

This trend of the rise of China and the continuing decline of the Western world on the African continent is increasingly annoying the Western powers. The latter no longer digest it. They want to contain it, to better reverse it at the risk of losing more of their interests, positions and influences on the continent (Makengo, 2020e: pp. 117-143). Thus, as also throughout the world, two blocs in power games are observed on the African continent, dominated respectively by United States and China. One is that of the "conservatives"-those who want to maintain their domination, power and influence on the continent, composed of the United States and its allies or close friends, and the other is that of the "progressives"- those who push for the change of the traditional geopolitical configuration on the continent, including China and its close friends, not to mention Russia. Two blocs that are ruthlessly engaging in "conservative-progressive power games" not only on the African continent, but also across the different corners of the world [and areas] considered strategic by both [as already pinned above]. These corners are understood as the different playgrounds on which these power games are played, including Africa.

\subsection{The Stakes of These Power Games on the African Continent}

It is quite clear that when talking about power games, the stakes should be there. What the players in game can win or lose. These stakes are multiple. They can be geopolitical, economic, financial, strategic, energetics, etc. Often, they are interrelated-just to illustrate: managing to control a given territory also reassures the exploitation or control of raw materials within it. And of course, they [these stakes] can change not only from one moment to another, but also from one field to another. Because Africa, it is first and foremost a market to be conquered. Since the colonial era, Africa has been the outlet of the great industrial powers. To date, the African market attracts even more with its 1.2 billion inhabitants, who are still projecting an upward trend-and with its young population, a human resources reservoir (United Nations, 2019: pp. 1-39). Then, it is the ground of the allies, friends or relatives sure to win. Since the end of the Second World War, the various African states have served as a basis for the projects and plans of the great powers, especially in various international organizations, not to mention the United Nations (UN), in terms of voting. To avoid 
being isolated or quasi-isolated, it is better to win the hearts, to date, of fifty-four (54) African states (Bush, 2017: pp. 1-24). And finally, Africa is also the land of various raw materials and [geopolitical] geostrategic to be won.

Indeed, since the colonial era, African raw materials and its geo-strategic position have constantly attracted the great powers in different corners of the continent. It is an open secret that African raw materials serve as essential "foodstuffs" for the industries of the great powers. Africa is really rich in raw materials. It has about $97 \%$ of the world's reserves of copper; $14 \%, 60 \%$ and $23 \%$ of those of oil, cobalt, uranium and phosphates respectively; $49 \%, 41 \%$ and $32 \%$ of those of platinum, vanadium and manganese respectively; $80 \%, 57 \%, 20 \%$ and $60 \%$ of those of columbite-tantalite (coltan), gold, iron and diamonds, etc. (Bassou, 2017: pp. 1-10). To date, it is important to underline here that not only these African raw materials mentioned above, but particularly its cobalt-attracting even more the various major powers within it-with the new global stakes of the energy transition and digital (Makengo, 2020b). But also the rise of China, its increasing dependence on African raw materials supply, further increases the strategic value of African raw materials (Makengo, 2020a). Because strategically speaking, for the conservatives, to contain the rise of China is also to seek to limit or reduce its supplies and control of African raw materials [the case of cobalt can better demonstrate this (Makengo, 2020b)]. Moreover, geo-strategically speaking, because of its position close to the Middle East, Africa is indeed part of the global energy supply route. Just as an illustration: I am thinking here of the Suez Canal. Similarly, it is the terrain of the strategic military bases of the great powers. Just one simple question can demonstrate this better: nowadays, of all these great powers- "conservative" and "progressive" alike-who has not [or has not already] its military and weapons to Africa? Although until further notice, China has only one base on the continent in Djibouti.

\section{COVID-19 as an Events' Accelerator: The Rise in Level of "Conservative-Progressive Power Games" in Africa}

As already noted above, COVID-19 is well suited to act as a gas pedal of events that are expected to occur over time. Among these events, I quote here the rise in level of the "conservative-progressive competition", represented here by United States and China respectively. Once again, as already shown above, this competition does not date back to COVID-19. It was well before COVID-19. The famous US-China trade war that began in 2018, which has been almost at a standstill since the beginning of 2020, can better demonstrate this (Makengo, 2020e). Similarly, the various strategies of the "conservatives" aimed at containing the rise of China can also better demonstrate this. I am thinking here of the "rebalancing strategy" (Khan \& Amin, 2015: pp. 3-28), the "pivot to Asia" (Clinton, 2011; Green, 2016), the "trans-pacific partnership strategy" and the "indo-pacific strategy” (Makengo, 2020e), all aimed at containing China's rise. COVID-19, has just served as a gas pedal to this competition through the US-China word war that it has caused-better "conservative-progressive word war"-around the ori- 
gin and management of the COVID-19 pandemic (Makengo, 2020c). This has implicitly signed the rise in level of "conservative-progressive power games" in different corners of the world and in areas considered strategic by both sides. I am thinking here of the rise of competition in the South China Sea and the technological warfare-the fifth generation of standards for mobile telephony (5G) in the lead... And Africa is no exception. During this pandemic, on the African continent, there is also a rise in level of these "conservative-progressive power games". The "conservatives", who at the beginning of this pandemic were more observant and critical, have now launched a [ferocious] offensive against the progressives-China, on the African continent. And the "progressives," who were also more on the offensive at the beginning, are now withdrawing from the defensive.

\subsection{The "Conservative Offensive"}

Delegitimizing China's rising power, seeking to isolate it, significantly reducing its possible support to African states, pushing it back and containing its growing presence on the continent-its stranglehold on African raw materials, these are the guidelines of the "conservative offensive" on the African continent during this era of the COVID-19 pandemic. In their offensive, the "conservatives" seek to portray themselves as the world's protectors against the "Chinese conspiracy". Thus, they present themselves as the "axis of good", and the "progressives"China, as the "axis of evil". In order to do so, they accuse and suspect China, without evidence [or excessively], of being the "originator" of COVID-19; of having succeeded in "bribing" the World Health Organization (WHO) to do as it pleases; of distributing "inappropriate" medical materials; of "concealing" certain information concerning the management of COVID-19 in its territory; of human rights "violations"; of "propaganda" and "pseudo-solidarity" in the distribution of its medical materials (Makengo, 2020c). After a time of observation and criticism of China's "medical diplomacy"- "progressive offensive", the Western powers-the "conservatives"- have woken up, and are now going on the offensive against the "progressives" in Africa. United States and its allies"the conservatives" - do not want to let go of Africa. Thus, their donations, aid and various "solidarity" initiatives are constantly arriving on the African continent during this period of the COVID-19 pandemic. And likewise, their visits and diplomatic contacts to Africa are constantly being made (Makengo, 2020c). Beyond the donations, aid, initiatives and US's contacts, I am also thinking here of those of its allies, notably the European Union (EU) humanitarian airlift to Africa. They [the "conservatives"] have gone even further, to the point of proposing the cancellation of the African debt-something that did not happen because of their divergence of interests with China, Africa's dominant partner until further notice-just a one-year moratorium that is being granted.

In a country like the Democratic Republic of Congo (DRC), where China has huge investments-particularly in the mining sector (Makengo, 2020a) -US's donations and aid keep coming one after the other. Likewise, the famous "hu- 
manitarian" airlift of its allies was not long in arriving in DRC. It is an open secret that: it is rather the new global stakes of the energy and digital transition that hide behind these donations, aid and other initiatives that continue to fall on DRC's territory. I am thinking here to the famous US's plan on strategic metals of our era and the Airbus project for European Union batteries. It is cobaltstrategic mineral of the energy transition, particularly in the automotive sector, indispensable in the production chain of electric and rechargeable hybrid vehicles, with the production of lithium-ion batteries-which DRC has a quasi-absolute advantage, about $60 \%$ of world production, and about $52 \%$ of world reserves-which China controls about $80 \%$-that attracts these various initiatives of solidarity, donations and aid to DRC's territory (Makengo, 2020b). And of course, just in the logic of being able to contain China, its domination in this matter.

\subsection{The "Progressives Defensive"}

Before and just at the beginning of the COVID-19 pandemic-after the Western world started being hit by COVID-19, the "progressives", here represented by China, were rather on the offensive on the African continent. The observation of China's increasing engagement in Africa before COVID-19 may well demonstrate this, expressing its position as the most dominant partner on the continent (see Figure 1, Figure 2) [I am also thinking of the resurrection of Russia's presence on the continent before COVID-19]. Rather, towards the beginning of the pandemic, it was through its "medical diplomacy" that its offensive on the continent was well manifested. China was the first to express its willingness to "help" African countries in the fight against COVID-19. Chinese medical equipment and personnel were arriving spectacularly on the African continent. In the name of Chinese "solidarity" with Africans, the wealthy Chinese Jack Ma was the first to send to all fifty-four (54) African countries the medical equipment needed to deal with COVID-19, including the famous masks and testing kits.

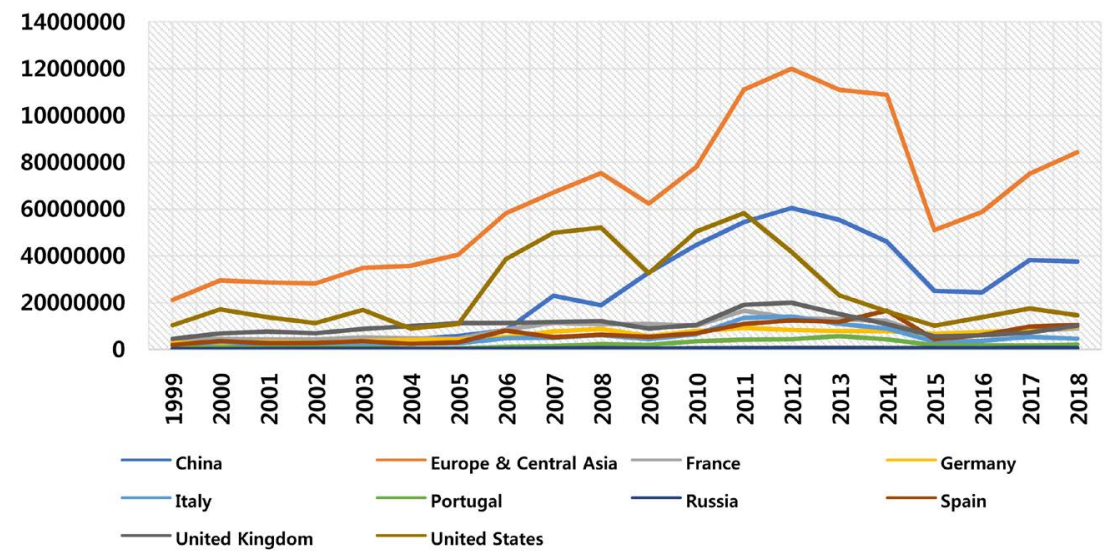

Figure 1. Evolution of exports from Sub-Saharan Africa to its selected partners (1999-2018). Source: Graphics designed by us based on our research data coming from World Integrated Trade Solution (WITS). 


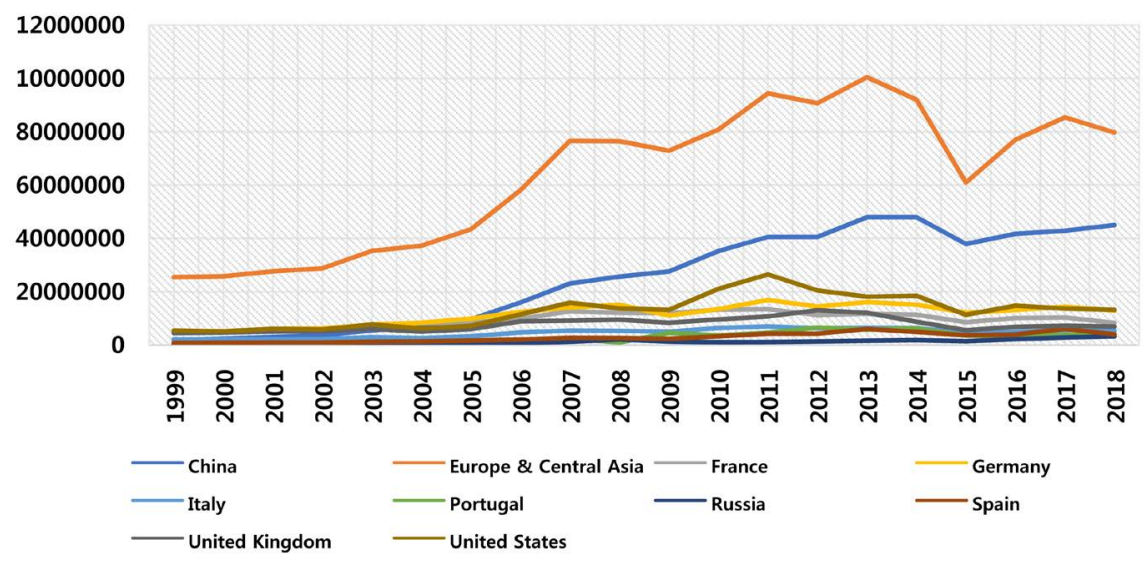

Figure 2. Evolution of Sub-Saharan African imports from selected partners (1999-2018). Source: Graphics designed by us based on our research data coming from World Integrated Trade Solution (WITS).

The Chinese government, for its part, has also done the same, sending its medical equipment in terms of donations and aid to the African continent. Beyond the online televised training that it [the Chinese government] has been able to organize for African states to learn more about COVID-19, it is its medical personnel who have sent it to various African countries-including DRC (Makengo, 2020c). But just after the "conservative offensive"-as pinned above China"progressive"-retreats more and more to the defensive-it is now coming to the defense. It defends itself fiercely against accusations, suspicions, decisions and actions of the conservatives to the detriment of its interests and image on the African continent-[but also in other parts of the world]. After it also speculated about the origin of COVID-19-suspecting the US military from the military games organized in Wuhan in October 2019-China continues to insist and demonstrate the natural origin of COVID-19. Especially since the majority of scientific studies by various virologists around the world, even those from the United States, including Dr. Anthony Fauci, are leaning more in its favor (Makengo, 2020c). Until proof to the contrary, the studies of these different virologists continue to insist on the natural origin of COVID-19 (Makengo, 2020e). As for other accusations and suspicions, China, in its defense, has been able to inject the media with a small cartoon synthesis video of about two (2) minutes, I quote: "Once upon a virus". Through this small video, China defends itself from the management of COVID-19 within its territory, its transparency towards the rest of the world and its relations with the $\mathrm{WHO}$ - just as a response to the allegations of the "conservatives" calling its management of COVID-19 "opaque" and "violations" of human rights.

Moreover, the offensive of donations, aid and other solidarity initiatives of the "conservatives" on the African continent, keeps China, with its donations, aid and other solidarity initiatives on the continent, just on the defensive. When the "conservatives" give, China- "progressive"-also gives, and vice versa. A "conservative-progressive competition" of donations, aid and other solidarity initia- 
tives in Africa that does not say its name. This can be seen in the different fields considered strategic by both sides. I quote here once again the DRC's case. Strongly, for reasons already highlighted above, since March 2020, DRC has been benefiting from donations, aid of all kinds and other solidarity initiatives from two sides-"conservative" and "progressive", these include medical equipment, funding and other assistance to health professionals. It is quite clear here that the two blocs-"conservative" and "progressive"-are ruthlessly jostling each other in the power games on the African continent. Thus, with the "conservative offensive" and China's defensive retreat, Sino-African relations are increasingly jostled in these power games in Africa in this COVID-19 era.

\subsection{Further Jostled of Sino-African Relations}

It is the "conservatives' communicational advantage" over the "progressives" on the African continent that ostensibly contributes to the more jostling of $\mathrm{Si}$ no-African relations during this period of COVID-19. The ability of "conservatives" to create, develop, access, provide and share information through verbal and non-verbal messages is stronger than that of China-the "progressives" (Makengo, 2020c). The "conservatives' communication" in Africa has more impact than that of China. Not surprising, because it is the "soft power" that is imposing itself in the communication process on the African continent during the COVID-19 era. Capacity to attracted and persuaded its targets and others by emphasizing its culture, values and foreign policy, rather than coercion (Nye, 2004: pp. 5-15). By the way, "soft power" is emphasized in these "conservative-progressive power games" in Africa. On the other hand, "hard power"-just showing up behind, serving as threats and influence in these games ${ }^{6}$. The following metaphor may well serve as an illustration: I give you my bread and favors, just follow my path, if you refuse, I will have to hit you.

And it is quite clear that the sum of the "conservatives' soft power" is seeing more powerfully than that of the "progressives"-China. This is ostensibly due to historical and communicational integration reasons. I quote here the colonial ties and heritages-sharing a certain number of "values", "democratic beliefs" for example - and cultural links-linguistic bases as an illustration-between the "conservatives" and the various African countries. And also, I am thinking here to the "conservatives' communication system"-their public diplomacy-which is more integrated in Africa than that of the "progressives". Until further notice, the clear conclusion is that the media of the "conservatives" have more inks on the African continent than those of the "progressives". Thus, the "conservatives' communications" are widely followed in Africa, and easily persuade Africans that those of the "progressives". Just on the issues of the origin and management of COVID-19 in China, the "conservatives" communications on this subject have ${ }^{6}$ The threats from conservatives on the African continent ostensibly cover the political dimension, but rather those from China directly cover the economic-financial dimension.

${ }^{7}$ Just as an illustration, as already pinned above: Western media have more inks in Africa than Chinese media. France 24, TV5, BBC, RFI, CNN... are better followed in Africa than CGTN, CCTV... 
ostensibly had more impact in Africa than those of the "progressives". Despite the old lies of the "conservatives" (Mearsheimer, 2011: pp. 1-182), Africa easily believes to the information or news that come from the Western world. It has only been necessary for the "conservatives" to raise the accusations and suspicions-about the Chinese virology laboratory P4 in Wuhan, the Huanan market in the same city (Makengo, 2020c), and the "opacity" of the management of COVID-19 on Chinese territory-for Africa to move, and to be increasingly persuaded to these "conservatives' accusations and suspicions"- and precisely to the detriment of China-the "progressives".

This has had a strong negative impact on China's image and legitimacy on the African continent. And it served as a springboard for the "conservatives" to shake up Sino-African relations. The "conservatives", through their communications, are constantly placing themselves in the "protective position" of the world against those they call the "Chinese conspiracy" (Makengo, 2020c). In this way, a fear of the unknown continues to stick to the Chinese presence in Africa. The information, donations, aid and other solidarity initiatives of the "conservatives" are almost successful in Africa, without asking many questions. But rather, those of China-the "progressive", are accepted with many questions, and raised the unknown fear. In DRC alone, where both blocs-“conservative" and "progressive"-are highly active [as already pinned above], public opinion is more interested in donations, aid and other "solidarity" initiatives that come from China than that the "conservative" ones. The news of the arrival of Chinese doctors on the territory of the DRC has created panic among Congolese public opinioncoming from the fear of the unknown. Similarly, Chinese medical equipment has ostensibly suffered from rumors and "fake news", creating psychosis in the public opinion of the DRC. On the other hand, those of the "conservatives" are accepted with less questions and panic. It is in this way that Sino-African relations are increasingly [or increasingly] jostled in these power games in Africa in this COVID-19 era. Thus, it is now necessary here to analyze whether or not Sino-African relations can withstand to these further jostled that they receive via the conservatives' offensive, under the wind of COVID-19.

\section{Can Sino-African Relations Withstand?}

It is not always easy to think about the future. But rather, this question of whether or not Sino-African relations can withstand or not in this era of COVID-19, brings the reflection of this present paper directly back to the future. Just like John Mearsheimer (2001) - in seeking to answer the famous question in his book The tragedy of the great Power politics, I quote: “Can China rise peacefully?', under-

${ }^{8}$ Market in the city of Wuhan where sea animals and other live animals of all kinds are sold, closed on January 1, 2020, initially considered abusively as the birthplace of COVID-19. U.S. President Trump and his Secretary of State Mike Pompeo constantly relayed this hypothesis in their conferences and media releases, even on Twitter, throughout the months of March and April. Qualifications such as "Chinese virus", "Wuhan virus" or "Kung Flu" were always on their agenda. A tone that ostensibly diminishes towards May, after the studies of the specialists, of the American intelligent community. 
lines, I quote: "Future hasn't happened yet". Thus, we need the facts and theories, which can be used to explain the future we want to project. By the resilience of Sino-African relations, I expect here by the capacity of these relations to be able to withstand the shocks that could bring them to the downfall [brink of collapse]. The shocks here come from the jostling of the "conservatives" through their [ferocious] offensive on the African continent during this era under COVID-19 wind. And the downfall here is understood as a pronounced collapse that the current level of these relationships would have to undergo to leave a void or hole that others would have to fill.

With regard to the futurological question raised here in this point, in order to answer it, I propose first to identify here two main assumptions that should serve as guidelines for my arguments, and then to set out the facts and theoryaccording to the assumptions put forward, which should serve as my explanation. The first assumption is quite simple: I assume that, yes, Sino-African relations can withstand. And for the second assumption, I suppose that the world is being hit by a socioeconomic-financial crisis due to COVID-19. And so, the socioeconomic-financial dimension should become a compass [but also a barometer] in the decisions and actions of the actors involved. The improvement of the socioeconomic-financial situation on its own territory would be the major challenge for the various actors involved. And it is in this way that the economic and financial crisis of 2008 is taken here as a case study to serve as explanatory facts. As a historical fact, this case of the 2008 crisis thus pushes this paper to take a step back in time, to go and see what had happened in terms of results-actors' behaviors in the power games in Africa under the subprime crisis, and to come to think about what could be the result-actors' behaviors in the "conservative-progressive power games" in Africa with the socioeconomic-financial crisis due to COVID-19. And so, this case serves here as an explanatory support for the two assumptions raised above. And finally, it is game theory that this paper is very interested in, just in terms of the theoretical basis for the explanatory analysis, following the ideas of the two assumptions raised above.

\subsection{What Can Be Said Here with the Subprime Crisis as a Historical Fact?}

The explanatory findings with this case of the subprime crisis are quite simple (Zestos, 2016: p. 274). I note here that during this crisis, the socioeconomic and financial dimension had indeed imposed itself as a compass [but also as a barometer] in the choice of decisions and actions of the actors in power games on the African continent. And the actors most affected by the crisis had quasiwithdrawn into the power games in Africa-because their main concern was now, I quote: the improvement of the socioeconomic and financial situation in their own territories hit by the crisis-at the risk of the rise in anger [tensions] of their public opinion-with all the political consequences that should follow. These worst-hit states were no longer able to bear the costs of their pre-crisis engagement on the African continent-a reduction in their engagement was thus 
observed on the continent (see Figure 1, Figure 2). While Africa, which was also hit by the same subprime crisis, was also thinking strongly about improving its socio-economic and financial situation-that its gross domestic product (GDP) growth was reduced by about 2 percent (BAD \& FAD, 2019: pp. 1-20). It was also ostensibly thinking about improving its socio-economic and financial situation for the reason linked to the risk already mentioned above [the pressure of the African public option]. This has largely contributed to the strengthening of Africa's relations with the actors at stake in the power games within the continent least affected by the subprime crisis (see Figure 1, Figure 2). As Figure 3 just shows, the most affected by this crisis was indeed the Western world-the "conservatives". And the years 2008 and 2009 were the years when their engagement in power games in Africa declined (see Figure 1, Figure 2). On the other hand, China was the least affected by this crisis (see Figure 3), and the years 2008 and 2009 were those of the more rise of its relations with the African continent.

This trend can be seen once again with the socioeconomic and financial crisis caused by COVID-19. Although for this one, the shocks are quite heavy. As the figure below (Figure 4) just shows, according to two quarters of GDP growth

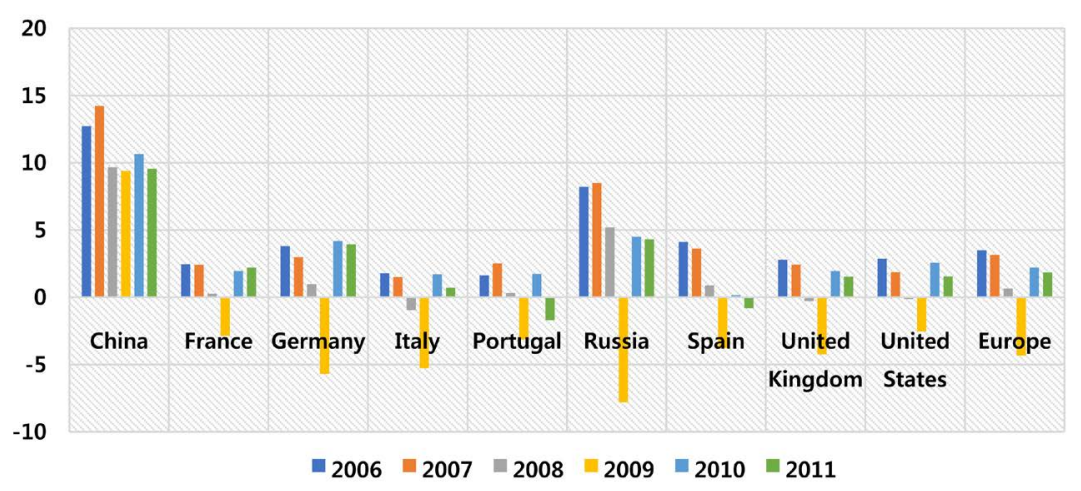

Figure 3. China, Russia and the Western World: GDP Growth under the subprime crisis (2006-2011). Source: Graphics designed by us based on our research data coming from Statista and Trading Economics.

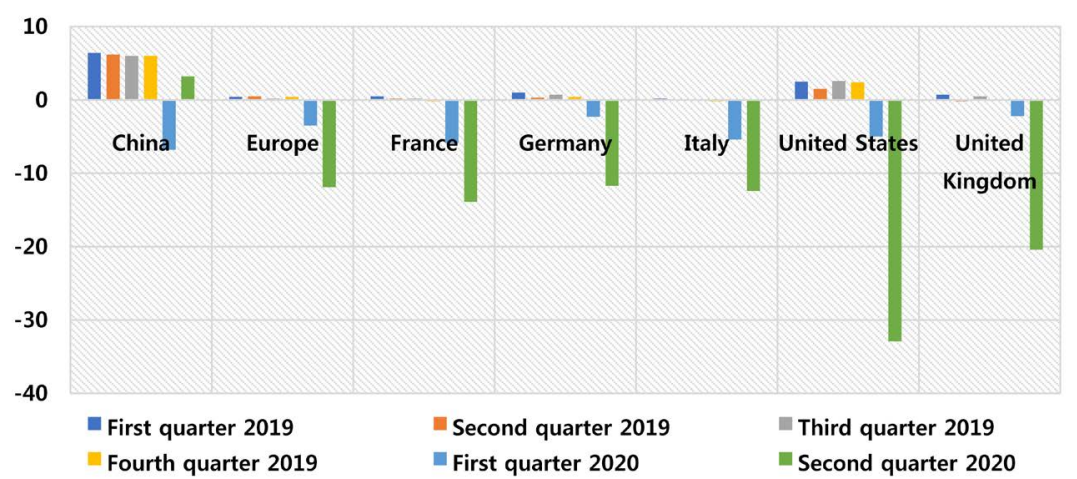

Figure 4. China and the Western World: GDP Growth under the COVID-19 Crisis (2019-2020). Source: Graphics designed by us based on our research data coming from Statista and Trading Economics. 
data of the actors in power games in Africa, it is the "conservatives"-the Western world-that are once again the hardest hit by the crisis caused by COVID-19. As can be seen from the free fall in their GDP growth rates to $-5 \%$ and $-32.8 \%$; and $-3.5 \%$ and $-11.9 \%$ in the first and second quarters for United States and Europe respectively. On the other hand, China- "progressive", is once again the least affected than the "conservatives"-via the fall in its GDP growth in the first quarter to $-6.8 \%$ and its rebound in the second quarter to $3.2 \%$. And similarly, as was the case with the 2008 crisis, Africa's GDP growth is once again projected to be lower with the COVID-19 crisis-a reduction estimated at about 2 percent (Chahed, 2020) [just as was the case with the subprime crisis].

It is from these explanatory findings that it is clear that Sino-African relations may well be withstand-although they may suffer just to quasi-stagnation in growth or relative decline, but of course, most likely less severe than the "Conservative-Africa relations" could be-because of the "comparative ConservativeChina shocks" with the COVID-19 crisis (see Figure 4). Also, Because the socioeconomic-financial dimension will once again become a compass [but also a barometer] in the decisions and actions of the various actors in power games in Africa-and of course, for those affected by the socioeconomic-financial crisis caused by COVID-19. Thus, the improvement of the socioeconomic and financial situation in their own territories will once again be their priority. These states, the most affected by the crisis, will be faced with the problem of bearing the costs of their engagement on the African continent-a reduction in their engagement should thus be noted [as was the case with the subprime crisis]. While Africa, in order to survive in the face of the crisis, which is also expected to impact it, will also focus on improving its socioeconomic and financial situation, which is expected to deteriorate with the shocks of the crisis caused by COVID-19. And the "conservatives"- the Western world-which would be the most affected by the crisis, will not be able to bear alone the burden of the African continent in the sense of satisfying African demands under pressure of the crisis. The costs of their engagement on the African continent will become very heavy for them, of course, because of their heavy shocks from the crisis due to COVID-19. And China, less affected by the crisis than them, will thus remain the source [or one of the important sources] palliative to the socioeconomic and financial shocks of the crisis due to COVID-19 on the African continent.

And finally, with game theory, this explanatory point of the resistance of Sino-African relations on the basis of the explanatory observations drawn from the subprime crisis's case of analysis is even better demonstrated.

\subsection{What to Say with Game Theory?}

The resilience of Sino-African relations in power games in Africa under the lee of COVID-19 is even clearer with game theory (Neumann \& Morgenstern, 1953: pp. 1-650). The postulates here are quite simple: each actor is quite rational, and 
sets up his own strategies to win good in the game, but these [their rationalities and strategies] are influenced or conditioned by the reality [or realities] of the moment [this can be endogenous or exogenous]. And of course, this reality here turns on the socioeconomic and financial dimension of COVID-19's impacts in their respective environments. Here, I imagine the "conservative-progressive power games" in Africa via a game with five (5) points to win in terms of gain on the African continent, precisely according to the costs or charges of its engagements, which are conditioned here by the reality of COVID-19 [Just as pinned above]. Four (4) possible scenarios are identified in this game-in red, green, blue and yellow respectively (see Figure 5). And through this game figure, the ultimate goal is to be able to identify the scenario as much as possible-[that can explain or say] the resistance or not of the Sino-African relations, in the power games in Africa under the lee of COVID-19.

Here, the observation is that this game just flows from the explanatory observations pinned above coming from the analysis case of the subprime crisis. It is clear that with the different scenarios outlined above in this game, Sino-African relations can indeed withstand. Following the logic of the above assumptions, the first and last scenarios in red and yellow, I quote: Sino-African relations and conservatives both withstand or conservatives collapse, but Sino-African relations withstand, are presented as the most possible scenarios in the "conservative-progressive power games" in Africa under COVID-19 wind. Rather, the first presents itself as the most possible scenario than the latter. Because China, less affected by the socioeconomic and financial crisis due to COVID-19, will still be able to bear the burdens or costs of its growing engagement on the African continent, despite the downward trend that would be observed [in its engagement on the continent], due to the drop in its economic activities affected by the crisis due to COVID-19 (see Figure 4). Similarly, if the "conservatives" fall, China will manage to fill to some extent the void left by the conservatives-as was just the case with the subprime crisis-but it would rather be a relative filling with the crisis due to COVID-19 because of the comparative negative impacts of the subprime crisis and the crisis due to COVID-19 on economic

\begin{tabular}{|c|c|c|c|c|c|c|}
\hline \multirow[b]{2}{*}{$\mathrm{A}, \mathrm{B}, \mathrm{C}$} & \multicolumn{6}{|c|}{ Costs/Charges to be paid and scores to be won } \\
\hline & 1.5 & 1 & 2.5 & 1 & 3.5 & 0.5 \\
\hline $\mathrm{A}, \mathrm{B}, \mathrm{C}$ & 4 & 0.5 & 0.5 & 2 & 0.5 & 2.5 \\
\hline \multicolumn{7}{|c|}{ Legend } \\
\hline \multicolumn{2}{|l|}{ A: Africa } & \multicolumn{5}{|c|}{ Sino-African relations and conservatives both withstand. } \\
\hline \multicolumn{2}{|l|}{ B: Conservatives } & \multicolumn{5}{|c|}{ Sino-African relations collapse, but Conservatives withstand. } \\
\hline \multicolumn{2}{|l|}{ C: China } & \multicolumn{5}{|c|}{ Sino-African relations and conservatives both collapse. } \\
\hline & & \multicolumn{5}{|c|}{ Conservatives collapse, but Sino-African relations withstand. } \\
\hline
\end{tabular}

Figure 5. Scenarios of the power games in Africa under the Wind of COVID-19. Source: Game's figure imagined by ourselves on the basis of our research data. 
activities in China (see Figure 3, Figure 4). But in case Sino-African relations fall, the "conservatives" - hard hit by the socioeconomic and financial crisis due to COVID-19 (see Figure 4), will not be able to bear the burdens and costs of their engagement in Africa in the sense of satisfying the various African countries or to fill the void left in Sino-African relations-it would be a loss of gain for the African continent. As the figure below just shows, how much China's investments in Africa represent in comparison to the shares of the "conservatives" and other partners on the continent (see Figure 6) [as well as Figure 1 and Figure 2 above, which show better in terms of trade: China's pronounced level of integration on the African continent compared to that of the "conservatives"].

While Africa, also hit by the same crisis due to COVID-19, will seek at all costs-as was the case with the subprime crisis-to improve its socioeconomic and financial situation hit by the crisis-despite the "conservative" pressure it might receive-to be able to shake China [isolate it]. This makes the second and third scenarios-green and blue, I quote: Sino-African relations collapse, but conservatives withstand or Sino-African relations and conservatives both collapse-the least likely. Rather, the third seems to be even less likely than the second. Just because of the reasons already raised above: variations in the costs/charges and earnings of different actors in the game-each actor may well maximize its chances of earning more or of being able to keep his earnings, but rather it should also be able to bear the costs or charges of its engagement-in proportion to his desired earnings; the pronounced economic and financial integration of China on the African continent compared to that of the "conservatives"- the fall of China will leave a big hole in African economies and finances [difficult to fill during this period of crisis neither by the "conservatives" nor by African countries themselves]; and the pronounced need for Africa [as well as for other actors affected by the COVID-19 crisis] to be able to improve its socioeconomic and financial situation negatively impacted by the COVID-19 crisis.

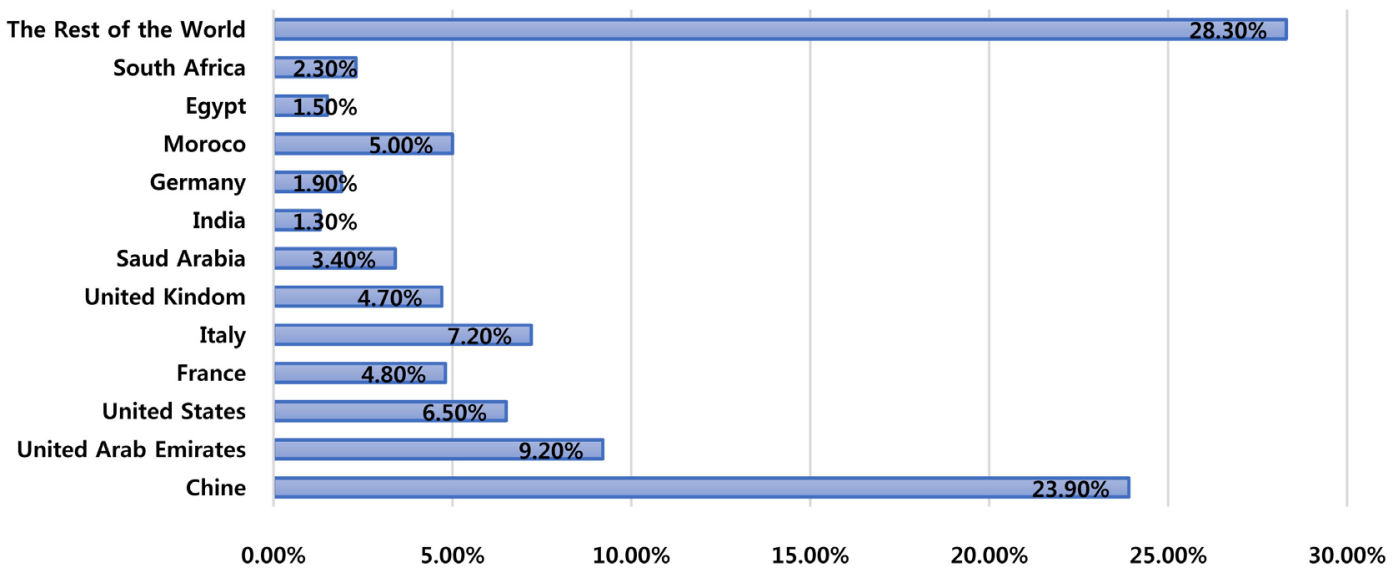

Figure 6. The top investors in Africa. Source: Graphics designed by us based on our research data coming from OECD report. 


\section{Conclusion}

Can Sino-African relations, increasingly shaken by the "conservatives" through their [ferocious] offensive on the African continent during this macabre period of sad memory under COVID-19 wind, withstand? This has been the central question in the debate and discussion of this paper. The later [this paper] modestly sets itself the objective not only to sketch the diachronic and synchronic configurations of power games in Africa [before and during COVID-19], to explain why these games were happened on the African continent, and to demonstrate the extent to which COVID-19 just accelerated them. But also to explain and demonstrate in a factual manner and on an explanatory theoretical basis, the question of whether or not Sino-African relations in these power games in Africa during the COVID-19 era could withstand or not.

After debate and discussion, the clear result that emerges shows that, although further jostled in these "conservative-progressive power games" in Africa during this period under COVID-19 wind, Sino-African relations may well withstand. For starting from the assumption raised here in this paper that assumes that, as was just the case with the subprime crisis, the socioeconomic and financial dimension will once again become a compass [but also a barometer] in the decisions and actions of all the states at stake-the "conservatives", the "progressives", as well as the different African countries. Thus, the improvement of the socioeconomic and financial situation on its own territory will become the major challenge of almost all these states at stake. And China, which is less affected by the socioeconomic and financial crisis caused by COVID-19 than the "conservatives", will be well able to bear the costs of its increasing engagement on the African continent. Although a relative decline or quasi-stagnation of its engagement on the continent can be noted-but rather less than in the case of the "conservatives", due of course to the comparative shocks of this crisis caused by COVID-19 on their economic activities. In this same logic, another explanatory point is that, if Sino-African relations fall, a big hole will be left in African economies-because of China's pronounced economic integration in Africa. A hole that the "conservatives"- hit hard by this crisis due to COVID-19, will not be able to fill during this critical moment, in the sense of satisfying the demands of Africa-which is also hit hard by the same crisis. The costs of the engagement of the "conservatives" on the continent will increase, while the costs of improving the socioeconomic and financial situation in their own territories, hit by the crisis due to COVID-19, are already weighing on them. Finally, the game theory as an explanatory theoretical basis, via the five (5) points game, imagined in terms of gain on the African continent, according to the costs of "conservativeprogressive engagements"-which are conditioned here by the socioeconomic and financial crisis due to COVID-19, demonstrates as well this affirmation of the resistance of Sino-African relations. In this game, following the assumptions put forward, the most possible scenario is indeed the first in red, I quote: SinoAfrican relations and "conservatives" both withstand. Because, China, less affected by the socioeconomic and financial crisis due to COVID-19, will still be 
able to bear the costs of its engagement on the African continent. But also, in the case of the fall of the "conservatives", China alone will not be able to fully cover the gap left by them due to the crisis caused by COVID-19, which also negatively impacted its economy and finances. And over here, the question is to ask: How will it be the continuation of these conservative-progressive power games in the post-COVID-19 era on the continent, the future of these games? How much will the engagements of two blocs in Africa be impacted under this COVID-19 wind? And how will Africa be impacted and come out in these games?

\section{Acknowledgements}

I thank here all my masters, elders and colleagues of University of Kinshasa (UNIKIN), China Foreign Affairs University (CFAU), Central China Normal University (CCNU) and of many other universities, who never cease to support and encourage me in my writings, to mention here only: Professor Théo-Macaire Kaminar Nsiy (UNIKIN); Professor Nkere Ntanda Nkingi (UNIKIN); Professor Kazumba K. Tshiteya (UNIKIN); Professor Jean-Pierre Lotoy Ilango-Banga (UNIKIN); Professor Émile Bongeli Yeikeo Ya Ato (UNIKIN); Professor Célestin Musao Kalombo (UNIKIN); Professor Jean-Gérard Baende (UNIKIN); Professor Héritier Mambi Tunga-Bau (UNIKIN); Professor Guy Aundu Matsanza (UNIKIN); Professor Arsène Bwenge Mwaka (UNIKIN); Professor Patience Kamanda (UNIKIN); Professor Jean Loyongo Empengele (UNIKIN); Professor Germain Kuna Maba Mambuku (UNIKIN); Professor José Banzozi (UNIKIN); Professor Godé Atshwel-Okel (UNIKIN); Professor Thomas Mawanzi Manzenza (UNIKIN); Professor Apollinaire Ipaya Ikoko (UNIKIN); Professor Patrice Bénis Mukulu Nduku (UNIKIN); Professor Félicité Langwana (UNIKIN); Professor Richard Kakesa Malundangu (UNIKIN); Professor Michel Bisa Kibul (UNIKIN); Chief of Works Willy Kalala (UNIKIN); Chief of Works Christel Mpongo Nziazi (UNIKIN); Professor Zhao Huaipu (CFAU); Professor Su Hao (CFAU); Professor Zhu Dandan (CFAU); Professor He Gang (CFAU); Professor Hu Zongshan (CCNU); Professor Zhao Changfeng (CCNU); Professor Zhang Xian (CCNU); Professor Liu Mingzhou (CCNU); Professor Wang Yonghui (CCNU); Professor Martin Parkes, Northwest A \& F University...

And finally, I sincerely thank here my dearest parents, Muadi Gaston and his wife, Émilienne Mungenga Masuna, and my brother, Faride Muadi Masso, for their permanent support to my modest person.

\section{Conflicts of Interest}

The author declares no conflicts of interest regarding the publication of this paper.

\section{References}

Banque Africaine de Développement et Fond Africain de Développement (BAD \& FAD). (2019). "L'effet de la crise financière mondiale sur l'Afrique", ECON Bureau de l'Eco- 
nomiste en chef. Abidjan: Banque Africaine de Développement et Fond Africain de Développement.

Bassou, A. (2017). Ressources naturelles et réalités géopolitiques de l'Afrique. Policy Brief, Rabat: OCP Policy Center.

Brocheux, P. (dir). (2012). Décolonisations au XXe siècle. La fin des empires Européens et Japonais. Paris: Armand Colin. https://doi.org/10.14375/NP.9782200249458

Bush, R. C. (2017). A One-China Policy Primer. Washington DC: Center for East Asia Policy Studies, Brookings Institution.

Chahed, N. (2020). Afrique/Coronavirus: Le PIB pourrait passer de 3,2\% à 1,8\% en 2020 (CNUCED).

https://www.aa.com.tr/fr/afrique/afrique-coronavirus-le-pib-pourrait-passer-de-3-2-\% C3\%A0-1-8-en-2020-cnuced/1781852

Chari, C. (Ed.). (2010). Superpower Rivalry and Conflict: The Long Shadow of the Cold War on the 21st Century. London: Routledge. https://doi.org/10.4324/9780203865330

Chatelus, M. (1974). Stratégies pour le Moyen Orient. Paris: Calmann Lévy.

Clinton, H. (2011). America's Pacific Century. Foreign Policy. https://foreignpolicy.com/2011/10/11/americas-pacific-century/

Encel, F. (2011). Le pétrole du Moyen-Orient est-il géo-politiquement si précieux? Réflexions autour d'une contestable centralité économique, stratégique et énergétique. Management \& Avenir, 2, 281-292. https://doi.org/10.3917/mav.042.0281

Green, M. J. (2016). The Legacy of Obama's Pivot to Asia. Foreign Affairs. https://foreignpolicy.com/2016/09/03/the-legacy-of-obamas-pivot-to-asia/

Grenouill, P. (2004). From Slave Trade to Empire: European Colonisation of Black Africa 1780s-1880s. London: Routledge. https://doi.org/10.4324/9780203323090

Hinnebusch, R. (2003). The International Politics of the Middle East. Manchester and New York, NY: Manchester University Press.

https://doi.org/10.7228/manchester/9780719053450.001.0001

Khan, Z., \& Amin, F. (2015). Pivot and Rebalancing: Implications for Asia-Pacific Region. Policy Perspectives, 12, 3-28. https://doi.org/10.13169/polipers.12.2.0003

Levinger, M. (2016). Why the U.S. Government Failed to Anticipate the Rwandan Genocide of 1994: Lessons for Early Warning and Prevention. Genocide Studies and Prevention: An International Journal, 9, 33-58.

https://doi.org/10.5038/1911-9933.9.3.1362

Lightbody, B. (1999). The Cold War. London: Routledge. https://doi.org/10.4324/9780203979143

Magnarella, P. J. (2005). The Background and Causes of the Genocide in Rwanda. Journal of International Criminal Justice, 3, 801-822. https://doi.org/10.1093/jicj/mqi059

Makengo, B. M. (2020a). China's Increasing Engagement in Africa: Opportunity and Futurisk for DRC's Sustainable Development. International Journal of Management Sciences and Business Research, 5, 191-216.

Makengo, B. M. (2020b). Competitive Globalization and Quest for Strategic Minerals: DRC's Cobalt at the Heart of New Global Stakes, towards the Resource's Trap? International Journal of Management Sciences and Business Research, 9, 51-75.

Makengo, B. M. (2020c). COVID-19 and US-China Word War: What Should Africa Do? International Journal of Innovation and Scientific Research, 48, 188-203.

Makengo, B. M. (2020d). COVID-19 et Jeux de puissance en Afrique: Les relations SinoAfricaines Peuvent-elles résister? International Journal of Management Sciences and 
Business Research, 9, 113-129.

Makengo, B. M. (2020e). Globalization and Power Strategies: A Look at the US-China Trade War. International Journal of Management Sciences and Business Research, 9, 117-143.

Makengo, B. M. (2021). COVID-19's Impacts and the End of Globalization? Open Journal of Social Sciences, 9, 212-233. https://doi.org/10.4236/jss.2021.91015

Mearsheimer, J. J. (2001). The Tragedy of Great Power Politics. New York, NY: W. W. Norton \& Company.

Mearsheimer, J. J. (2011). Why Leaders Lie: The Truth about Lying in International Politics. Oxford: Oxford University Press.

Mearsheimer, J. J. (2018). Great Delusion: Liberal Dreams and International Realities. New Haven, CT: Yale University Press. https://doi.org/10.2307/j.ctv5cgb1w

Neumann, J. V., \& Morgenstern, O. (1953). Theory of Games and Economic Behaviour (3rd ed.). Princeton, NJ: Princeton University Press.

Nye, J. (1991). Bound to Lead: The Changing Nature of American Power. New York, NY: Basic Books.

Nye, J. (2004). Soft Power: The Means to Success in World Politics. New York, NY: PublicAffairs.

Nye, J. (2008). The Powers to Lead. Oxford: Oxford University Press.

Nye, J. (2011). The Future of Power. New York, NY: PublicAffairs.

Oliver, R. A., \& Atmore, A. (2005). Africa since 1800. Cambridge: Cambridge University Press. https://doi.org/10.1017/CBO9780511800283

Reyntjens, F. (2009). The Great African War: Congo and Regional Geopolitics, 1996-2006. New York, NY: Cambridge University Press. https://doi.org/10.1017/CBO9780511596698

Tristani, P. (2010). L'Iraq Petroleum Company, les États-Unis et la lutte pour le leadership pétrolier au Moyen-Orient de 1945 à 1973. Histoire, économie \& société, 2, 81-107.

United Nations, Department of Economic and Social Affairs, Population Division (2019). World Population Prospects 2019: Highlights (ST/ESA/SER.A/423). New York, NY: United Nations.

Zestos, G. K. (2016). The Global Financial Crisis: From US Subprime Mortgages to European Sovereign Debt. London: Routledge. https://doi.org/10.4324/9781315755595 